\title{
Report on the collision between a spinner dolphin and a boat in the Fernando de Noronha Archipelago, Western Equatorial Atlantic, Brazil
}

\author{
Fernanda Scarano Camargo ${ }^{1,3} \&$ Claudio Bellini $^{2}$ \\ Biota Neotropica $v 7(n 1)$ \\ http://www.biotaneotropica.org.br/v7n1/pt/abstract?short-communication+bn00807012007 \\ Data Received 30/05/06 \\ Revised 25/10/06 \\ Accepted 01/01/07 \\ ${ }^{1}$ Instituto de Biociências, Universidade de São Paulo, Rua do Matão, Travessa 14, 321, \\ Cidade Universitária, CEP 05508-900, São Paulo, SP, Brazil \\ ${ }_{2}^{2}$ Projeto TAMAR, Alameda do Boldró, s/n, CEP 53990-000, Fernando de Noronha, PE \\ www.projetotamar.org.br \\ ${ }^{3}$ Corresponding author: Fernanda Scarano Camargo, e-mail: fscamargo@yahoo.com,www.ib.usp.br
}

\begin{abstract}
Camargo, F.S. \& Bellini, C. Report on the collision between a spinner dolphin and a boat in the Fernando de Noronha Archipelago, Western Equatorial Atlantic, Brazil. Biota Neotrop. Jan/Apr 2007 vol. 7, no. 1 http://www.biotaneotropica.org.br/v7n1/pt/abstract?short-communication+bn00807012007 ISSN 1676-0603.

This paper reports a case of collision between an individual spinner dolphin and a boat in the Fernando de Noronha Archipelago, as an example of disturbance potentially caused by tourism industry activities. Photos illustrating the inflicted injuries on the animal are presented, and preventive measures to avoid this kind of accidents are proposed. This is the first report on a collision between spinner dolphins and boats.

Keywords: spinner dolphins, Stenella longirostris, collision, disturbance, Fernando de Noronha.

Resumo

Camargo, F.S. \& Bellini, C. Relato de colisão entre um golfinho-rotador e uma embarcação no Arquipélago de Fernando de Noronha, Atlântico central equatorial, Brasil. Biota Neotrop. Jan/Apr 2007 vol. 7, no. 1 http://www.biotaneotropica.org.br/v7n1/pt/abstract?short-communication+bn00807012007 ISSN 1676-0603.

Neste artigo, um caso de colisão entre um golfinho-rotador e uma embarcação é registrado no arquipélago de Fernando de Noronha, como um exemplo de perturbação causada potencialmente por atividades turísticas. São apresentadas fotografias ilustrando os ferimentos causados no animal e o uso de medidas de prevenção para evitar este tipo de acidentes é proposto. Este é o primeiro registro de colisão entre golfinhos-rotadores e embarcações.
\end{abstract}

Palavras-chave: golfinhos-rotadores, Stenella longirostris, colisão, perturbação, Fernando de Noronha. 


\section{Introduction}

Boat traffic is widely believed to cause disturbance to cetaceans and sirenians and is frequently reported as an important threat to their welfare and conservation (Goodwin \& Cotton 2004). Many interactions between cetacean and boats are presumably explained as a reaction of these animals to sound, as boat engines produce high levels of underwater noise, which results in behavioral changes, short and long term displacement, masking of echolocation signals, and physiological stress (Evans et al. 1992, Richardson et al. 1995, Richardson \& Würsig 1997).

Collisions, on the other hand, can cause direct physical injury and death (Nowacek et al. 2001; Wells \& Scott 1997). Several species of cetaceans including the humpback whale (Megaptera novaeangliae) (Smultea 1989, Swingle et al. 1993), right whales (Eubalaena glacialis and Eubalaena australis) (Colborn et al. 1998, Laist et al. 2001), bottlenose dolphins (Tursiops truncatus) (Fertl 1994, Wells \& Scott 1997) and killer whales, Orcinus orca (Ford et al. 1994, Visser 1999), have been documented as being hit by vessels. In some instances, the occurrence of an accidental collision between cetaceans and boats can be identified by scars, which are usually found on the dorsal surface of the animal (if the animal was hit while alive). Damage due to strikes of propeller blades usually results in a series of large parallel cuts along the dorsal surface of the animal (Angliss \& DeMaster 1997). Wells and Scott (1997) have studied bottlenose dolphins in Florida, and have reported a number of individuals showing straight and deep cuts into the dorsal fin or body. The multiple cuts are parallel and evenly spaced, with the spacing similar to that recorded for propeller scars on manatees, Trichechus manatus, in the same area (Wright et al. 1995).

This article aim to report a case of collision between an individual spinner dolphin and a boat that occurred in the Archipelago of Fernando de Noronha off Brazil, using photographs to evidence injuries suffered by the animal.

\section{Material and Methods}

Our record was made at the Fernando de Noronha Archipelago $\left(3^{\circ} 51^{\prime} \mathrm{S}\right.$ and $32^{\circ} 25^{\prime} \mathrm{W}$ ), off Brazil. Most of the archipelago is included in the National Marine Park of Fernando de Noronha, where human activities including visitation are controlled.

Photographs of spinner dolphins, Stenella longirostris (Gray 1828) at the Baía dos Golfinhos, Fernando de Noronha Island, were used to identify injuries. The Baía dos Golfinhos is a cove that carries this name because is visited daily by groups of spinner dolphins (Lodi \& Fiori 1987). It is an intangible inlet inside the marine park, in which the regular access of people and boats is prohibited. Although a series of protection laws has been already created to preserve organisms and their environment, especially spinner dolphins, the long-term effects of tourism activities are still unclear (for example: Silva et al. 1999; Silva \& Silva Jr. 2002).

\section{Results and Discussion}

On April 26, 2006 we photographed a spinner dolphin inside the cove "Baia dos Golfinhos", which presented the two jaws broken and parallel cuts along its body (Figure 1). Both injuries were strongly indicative that the dolphin had been hit by a boat. As the dolphin was very emaciated and moved arduously, we considered the accident as a fatal one. However, as we don't know how far spinner dolphins move around the archipelago, we are thus unable to say that the accident happened close to the Marine Park, and, thus, inside the

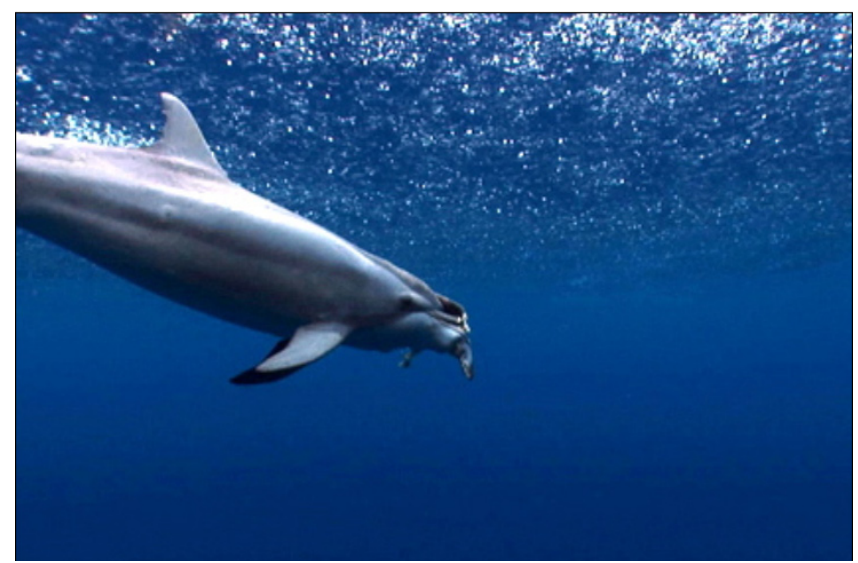

(a)

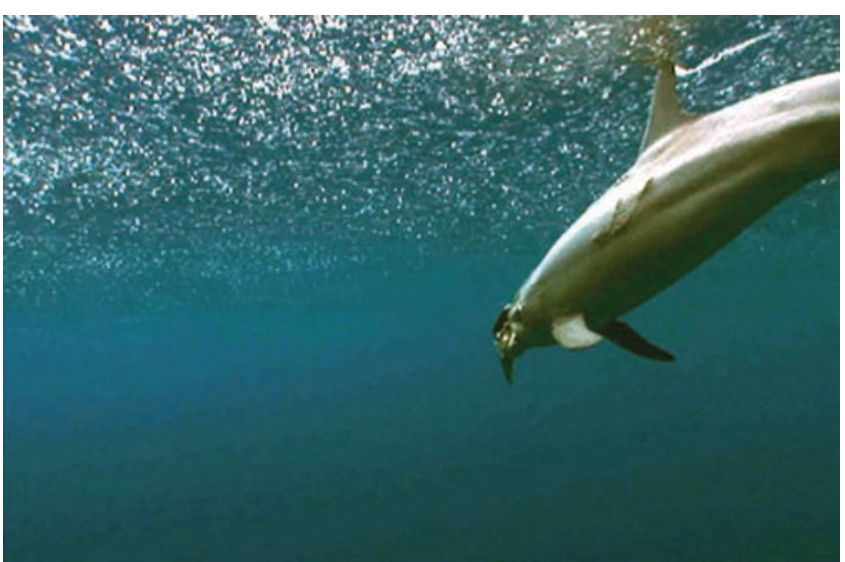

(b)

Figure 1. A spinner dolphin (Stenella longirostris) with its two jaws broken as a result of boat propeller strike a); the same individual showing two parallel cuts in the body b).

Figura 1. Um golfinho-rotador (Stenella longirostris) com as duas maxilas quebradas como resultado de uma colisao com a helice de um barco a); o mesmo individuo mostrando dois cortes paralelos no corpo b).

protected areas. Considering that (i) the tourism industry has remarkably increased during the last decade; (ii) tourism is nowadays the most important economic activity in the archipelago and (iii) even occasional mortality of a few dolphins as a result of disturbance is undesirable and often illegal, we believe that use of simple preventive tools -such as educating local people and visitors and installing propeller guards on boats that are in regular contact with cetaceans (Visser 1999) - is strongly recommended in order to avoid these kinds of accident.

\section{Acknowledgments}

We thank Ligia Bellini, Otto Bismarck Fazzano Gadig and Mario M. Rollo Jr. for the important suggestions and for reviewing the earlier version of the manuscript, and the anonymous reviewer who made useful suggestions for improving the manuscript. Finally, we thank CAPES and Projeto TAMAR for the financial and logistical support and IBAMA for giving the necessary permits to data collection inside the National Marine Park of Fernando de Noronha. 


\section{References}

ANGLISS, R.P. \& DEMASTER, D.P. 1997. Guidelines for Differentiating Serious and Non-Serious Injury of Marine Mammals Taken Incidental to Commercial Fishing Operations: Report of the Serious Injury Workshop, 1-2 April 1997, Silver Spring, MD. U.S. Dep. Commer., NOAA Tech. Memo. NMFS-OPR-13, 48p.

COLBORN, K., SILBER, G., SLAY, C. 1998. Avoiding collisions with right whales. Professional Mariner 35: 24-26.

EVANS, P.G.H., CANWELL, P.J., LEWIS, E.J. 1992. An experimental study of the effects of the pleasure craft noise upon bottlenose dolphins in Cardigan Bay, West Wales. In European Research on Cetaceans 6: Proceedings of European Cetacean Society: 43-46. (P.G.H. Evans, ed.). European Cetacean Society, Cambridge.

FERTL, D. 1994. Occurrence patterns and behavior of bottlenose dolphin (Tursiops truncatus) in the Galveston Ship Channel, Texas. Texas Journal of Science 46(4):299-317.

FORD, J.K.B., ELLIS, G.M., BALCOMB, K.C. 1994. Killer whales: the natural history and genealogy of Orcinus orca in British Columbia and Washington State. Vancouver, University of British Columbia Press. $102 \mathrm{p}$.

GOODWIN, L. \& COTTON, P.A. 2004. Effects of boat traffic on the behavior of bottlenose dolphin (Tursiops truncates). Aquatic Mammals 30(2):279-383

GRAY, J.E. 1828. "Specilegia Zoologica; or original figures and short systematic description of new and unfigured animals". London: Treuettel, Wurtz and Wood.

LAIST, W.D., KNOWLTON, A.R., MEAD, J.G., COLLET, A.S., PODESTA, M. 2001. Collisions between ships and whales. Marine Mammal Science 17(1):35-75.

LODI, L., FIORI, B. 1987. Observações sobre o comportamento do golfinhorotador, Stenella longirostris (Cetácea: Delphinidae) na Ilha de Fernando de Noronha - Brasil. Segunda Reunião de Trabalhos de Especialistas em Mamíferos Aquáticos da América do Sul. Rio de Janeiro: FBCN. p. 60-68 (Anais)

NOWACEK, S.M., WELLS, R.S., SOLOW, A.R. 2001. Short-Term effects of boat traffic on bottlenose dolphins, Tursiops truncatus, in Sarasota Bay, Florida. Marine Mammal Science 17(4):673-688.

RICHARDSON, W.J., GREENE JR, C.R., MALME, C.I., THOMSON, D.H. 1995. Marine mammals and Noise. Academic Press, San Diego, USA and London, UK. 576 p.

RICHARDSON, W.J. \& WÜRSIG, B.E. 1997. Influences of man-made noise and other human actions on cetacean behavior. Marine and Freshwater Behavior and Physiology 29(1-4):183-209.

SILVA, F.J.L., SILVA JÚNIOR, J.M., YAMAMOTO, M.E., CHELLAPA, S 1999. Influence of tourism in the frequency of dolphins Stenella longiros- tris in Fernando de Noronha, Brasil. In $13^{\text {th }}$ Biennial Conference on the Biology of Marine Mammals (P. Nachtigall, Ed.), Wailea, Maui, Hawaii: Society for Marine Mammalogy (Abstract Book). p. 172.

SILVA, F.J.L. \& SILVA JÚNIOR, J.M. 2002. Incremento do turismo e implicação na conservação dos golfinhos rotadores no Parque Nacional Marinho de Fernando de Noronha. In III Congresso Brasileiro de Unidades de Conservação: Rede Nacional Pró-Unidades de Conservação, Fundação O Boticário de Proteção à Natureza e Associação Caatinga (Anais), Fortaleza, Brasil. p. 135-144.

SMULTEA, M. 1989. Humpback Whales off West Hawaii. Whalewatcher 23:11-14.

SWINGLE, M.W., BARCO, S.G., PITCHFORD, T.D., MCLELLAN, W.A., PABST, D.A. 1993. Appearance of juvenile humpback whale feeding in nearshore water of Virginia. Marine Mammal Science 9: 309-315.

VISSER, I.N. 1999. Propeller scars on and known home range of two orca (Orcinus orca) in New Zealand waters. New Zealand Journal of Marine and Freshwater Research 33: 635.642.

WELLS, R.S. \& SCOTT, M.D. 1997. Seasonal incidence of boat strikes of bottlenose dolphin near Sarasota, Florida. Marine Mammal Science 13. 475-480.

WRIGHT, S.D., ACKERMAN, B.B., BONDE, R.K., BECK, C.K. \& BANOWETZ, D.J. 1995. Analysis of watercraft-related mortality of manatees in Florida, 1979-1991. In Population biology of the Florida manatee. (T.J. O’Shea; B.B. Ackerman; H.F. Percival, eds.). National Biological Service Information and Technology Report 1: 259-268.

Title: Report on the collision between a spinner dolphin and a boat in the Fernando de Noronha Archipelago, Western Equatorial Atlantic, Brazil.

Authors: Camargo, FS e Bellini, C

Biota Neotropica, Vol.7 (number 1): 2007 http://www.biotaneotropica.org.br/v7n1/pt/abstract?shortcommunication+bn00807012007

Data Received 30/05/06 - Revised 25/10/06 Accepted 01/01/07

ISSN 1676-0603 